\title{
An Investigation of the Impact of Foreign Direct Investment on Economic Growth: A Case Study of Mauritania
}

\section{Limam Ould*}

Faculty of Economics and Management Sciences, International Islamic University Malaysia, Selangor, Kuala Lumpur 53100, Malaysia

\begin{abstract}
Purpose: This paper aim to investigate the impact of Foreign Direct Investment (FDI) on the economic growth of Mauritania for the period 1976 to 1995 quarterly data. It evaluated the Gross Domestic Product (GDP) performance and the trends of FDI and Gross Fix Capital Formation (GFCF) in Mauritania.

Methodology/sample: to demonstrate the relationship between Mauritanian Gross Domestic Product (GDP) and Foreign Direct Investment (FDI) and Gross Fix Capital Formation (GFCF) Multiple-Regression-Model has been applied along side with various econometrics techniques such as Unit-Root Test, Granger-Causality Test and Ordinary Least Square (OLS). GDP in this model is used as dependent variable whereas FDI and GFCF are measured as independent variables.

Findings: According to the results, Unit Root Test indicated that all the variables included in the model were not stationary at level except FDI, whereas GDP and GFCF are stationary at first difference. The model is overall significant with the positive and significant relationship of GDP, FDI and GFCF (divya). Result also indicate a good fit for the model with R2=85\%. The Granger Causality Test revealed that there was no causality between the variables since all $p$-value obtained are more than $5 \%$.

Practical implications: Based on the empirical result of this paper, policy recommendation proposed that for Mauritania to generate more foreign direct investment, hard work should be made at solving problems of government involvement in business; relative closed economy; corruption; weak public institutions; and poor external image, and political instability.
\end{abstract}

\section{Keywords: GDP; FDI; GFCF; Mauritania}

\section{Introduction}

Foreign Direct Investment (FDI) is seemed to have a positive influence on the economic growth of the developing countries through direct and indirect ways. It increases the domestic investment, which is claimed to have crucial role on the sustainability of growth and development. As a result, many developing countries, including Mauritania, have presented munificent intensives in order to attract FDI inflow.

Foreign direct investment incentives may be in shape of low corporate and income tax rates, tax holidays, other types of tax concessions, preferential tariffs, special economic zones, investment financial subsidies, soft loan or loan guarantees, free land or land subsidies, relocation and expatriation subsidies, job training and employment subsidies, infrastructure subsidies, research and development support and derogation from regulations, usually for very large projects [1]. However, This important incentives offered by developing countries have been taken by foreign firms to fulfil their objective by increasing profits through numbers of advantage such as control over local market, low cost of labour.

Developing countries undertake some macroeconomic reforms to ensure investor-friendly environment. The positive impact of FDI inflow has been increasingly famous as a vital tool to encourage economic growth [2]. The pivotal effect of FDI inflow on economic growth encompass, an increase in aggregate productivity, an increase opportunities of employment, a greater outflow of export, and finally exchange technology advancement between investor and the country [3]. According to a number of studies such as [4] foreign direct investment can serve as a means of transfer of technology and knowledge [4].

In case of Mauritania, although the country being blessed with huge natural resources but it recorded very low proportion of global
FDI inflow. As a part of sub-Saharan countries Mauritania has been relatively open to FDI. The attractive natural resource in mining, fishing and hydrocarbon sectors helped the country to acquire inflow. Even though FDI flows to West Africa declined by $5 \%$ to $\$ 16.8$ billion, Mauritania mining sector helped the country to obtained double inflow to \$ 1.2 [5]. Mauritania works with the International Monetary Fund (IMF), the World Bank (WB), and the international donor community to move forwards basic infrastructure projects and to update laws and regulations.

This paper aims to discover the impact of foreign direct investment (FDI) on Mauritania economic growth (GDP) for the period 1976 to 1995 quarterly data and to observe the relationship between (GDP) and Gross Fixed Capital Formation (GFCF). Mauritania is a country located at the North West Region of Africa and constitutes as part of subSaharan African countries. It has a total population of 3,437,610. Based on the latest Central Intelligence Agency's report Mauritania has a total GDP of $\$ 7.824$ billion [6]. Mauritania economy primarily depends on mining and fishery sectors, a per capita income is low, and much of the population lives under poverty line. Therefore policies to benefit from FDI inflow in the country are the vital objectives of the macroeconomic policy makers. Mauritania is strives to fight against effects of global panic such as unemployment rise, shortage liquidity. FDI and GFCF

*Corresponding author: Limam Ould, Faculty of Economics and Management Sciences, International Islamic University Malaysia, Selangor, Kuala Lumpur 53100, Malaysia, Tel: (+603) 6196 4000; E-mail: limam.uia@gmail.com

Received December 17, 2014; Accepted January 27, 2015; Published February 04, 2015

Citation: Ould L (2015) An Investigation of the Impact of Foreign Direct Investment on Economic Growth: A Case Study of Mauritania. Int J Econ Manag Sci 4: 224 doi: 10.4172/2162-6359.1000224

Copyright: (c) 2015 Ould L. This is an open-access article distributed under the terms of the Creative Commons Attribution License, which permits unrestricted use, distribution, and reproduction in any medium, provided the original author and source are credited. 
play a very crucial role in its future growth and development.

\section{Literature Review}

A variety of theoretical and empirical studies are presented on the impact of Foreign Direct Investment and Economic Growth in both developed and developing countries. Majority of these studies have been done on the international level. In context of Mauritania, there is dearth of empirical studies regarding these types of economic subject. A numerous of important researches have been critically reviewed to build up objectives in the perspective of Mauritania and further to analyse it to draw important conclusion and policy recommendations.

Laura Alfaro et al., they check up the various links among FDI and GDP growth. They explore whether countries with better financial systems can exploit FDI more efficiently. The empirical analysis used data between 1975 and 1995. Result shows that FDI alone plays an ambiguous role in contributing to economic growth. However, countries with well developed financial markets gain significantly from FDI in their economic growth [7]

Frimpong [8] explored the relationship between FDI and GDP growth for Ghana for the pre and post structural adjustment program (SAP) periods and the direction of the causality between two variables. Annual time series data covering the period from 1970 to 2005 was used. The study finds no causality between FDI and growth for the total sample period and the pre-SAP period [8].

Ayanwale [9] examine the empirical relationship between nonextractive FDI and economic growth in Nigeria. The study applied Ordinary Least Square (OLS) technique. Result indicates that FDI had a positive impact on economic growth [9].

Another work by Herzer et al., [10] used a bi-variate Vector Autoregressive (VAR) Model to figure out the impact of FDI in some developing countries. The study discovered evidence of a positive FDIled growth for Nigeria, Sri Lanka, Tunisia, and Egypt and based on weak exogeneity tests, a long-run causality between FDI and economic growth running in both directions was found for the same countries [10].

Chin-Chiang et al, [11] they check up whether the FDI promote the economic growth by using threshold regression analysis. The empirical analysis revealed that FDI alone play a vague role in contributing to economic growth based on a sample of 62 countries covering the period from 1975 to 2000 and find that initial GDP and human capital are important factor in explaining FDI. FDI is found to have a positive and significant impact on growth when host countries have better level of initial GDP and human capital [11].

Nuzhat Falki [12] explored the effect of FDI on the Economic Growth of Pakistan. She collected the data that covers the period 1980 to 2006 from the Handbook of Pakistan Economy-2005 published by the State of Pakistan and the World Bank Development Indicators. Variables of domestic capital, foreign owned capital and labour force were used in this study with the help of endogenous growth theory and applying the regression analysis. The finding revealed a negative statically insignificant relationship between GDP and FDI inflows in Pakistan [12].

Sayeed Alam and Mahmud Zubayer they founded that in SAARC FDI from outside is more important than in intra regional investments in most the countries (the only exception is Nepal) where Indian investments dominated. The concept of some region can be applicable to increase intra regional FDI. The FDI has a significant impact on GDP of SAARC countries.

Abel and Nikki [13] investigated the effect of macroeconomics variables on the foreign direct investment of 30 Sub-Sahara African (SSA) countries between 1995 and 2008. Result, showed that financial development, the size of market and infrastructural development and urban accumulations are important factors that measure the inflows of FDI to the SSA region [13].

Behname [14] used random effects model to determine the impact of foreign direct investment on economic growth in Southern Asia. The study concluded that foreign direct investment has positive and significant effect on economic growth [14].

Onakoya [15] disaggregated the economy and employed a structural macro- econometric model consisting of four blocks namely: supply, private demand, government and external sectors to measure the impact of FDI on economic growth. The findings showed that FDI has a significant impact on output of the economy, however, the growth effects of FDI differs across sectors in Nigeria [15].

Abbas et al. [16] investigated the influence of FDI and CPI on the GDP's of SAARC member nations. The findings indicated that the general model in these countries developed a positive relationship between Foreign Direct Investment and GDP while negative relationship between Consumer Price Index and GDP. This conclusion was tested using the multiple regression models. The data of the SAARC countries ranged from the year 2001 to 2010 [16]. Esther and Folorunso [17] explored the relationship between FDI inflows and economic growth of Nigeria. The findings reported that FDI influence economic growth positively to limited human capital [17].

A study by Zakia and Ziad [18] investigated the impact of FDI on the economic growth of Jordan. The empirical results revealed that there is existence of bidirectional relationship between FDI and output [18].

Kashif and Muhammad [19] investigated the impact of FDI on Pakistan economic growth. The study developed an auto regressive distributed lag (ARDL) model. The model examines long run relationship between the variables and found absence of long run relationship between FDI and economic growth [19].

\section{Research Methodology}

The purpose of this research paper is to examine the impact of FDI inflow on the economic growth of Mauritania (GDP) and the relationship between Gross Fix Capital Formation (GFCF) and GDP. Study covers the time period from 1976-1995. The quarterly data obtained form World Bank Indicator (WBI) which is considered as an authentic source of data collection. To examine the relation of Mauritania's GDP with FDI and (GFCF), the following theoretical model is used.

$\mathrm{GDP}=\mathrm{F}(\mathrm{FDI}$ and GFCF)

The hub intention of the paper is to study the effect of FDI on GDP of Mauritania. The trend of foreign Direct Investment inflows is also observed with relevance to GDP growth and GCFCF. To examine the relation of Mauritania's GDP with FDI and GFCF, the following multiple regression model is used,

$\mathrm{GDP}=\alpha+\beta 1 \mathrm{FDI}+\beta 2 \mathrm{GFCF}+\mu$

Where, 
FDI $=$ Foreign Direct Investment

GDP $=$ Gross Domestic Product

GFCF $=$ Gross Fix Capital Formation

Level of Significant: 5 to 10 percent

\section{Method of data analysis}

In analysing the dataset the following tests are expected to be employed: Unit root test for stationary, Augmented Dickey-Fuller Test (ADF), Ordinary Least Square (OLS) method, Granger causality test was applied in order to determine the presence of the relationship among variables and its direction (Granger, 1969). The study used E-views 6 software to analyse data.

\section{Empirical Results}

\section{Descriptive statistic}

The Multiple Regression Model was run on E-Views to find out the Impact of FDI and GFCF on the Gross Domestic Product of Mauritania. In this multiple regression model, GDP is used as dependent variable whereas FDI and GFCF are defined as independent variables. To estimate the effect of FDI on GDP of Mauritania, Multiple Regression Model is applied over the period of 1976 to 1995 quarterly. Descriptive statistics of GDP, FDI and GFCF are as follows.

The Table 1 showed a summary of the descriptive statistic for the three variables included in this study GDP, FDI, and GFCF. The table contains the mean, standard deviation, minimum and maximum for 80 observations covering the period 1976-1995 quarterly.

\section{Measures the dependent variable (GDP)}

In this study we used GDP as a dependent indicator in the Multiple Regression Model. Quarterly data covers the period from 1976-1995, and it is taken from WBI. GDP measured in Million US\$. It is used as dependent variable. The result from descriptive statistic indicates that Mauritania real GDP recorded 24.8 Million US\$. The minimum value of real GDP was 23.8 Million US\$, while the maximum value was 25.9 Million US\$ (Figure 1).

\section{Measures the Independent Variable (FDI)}

We used FDI as an independent growth in Multiple Regression Model. Quarterly data cover the period from 1976_1995 obtained from WBI. FDI measured in Millions of US\$. The finding showed that Mauritania real FDI inflow recorded 15.52 Millions US\$. The Minimum value was 14.12 Million US\$, while Maximum value recorded 17.96 Million US\$ (Figure 2).

\section{Measures of Independent Variable (GFCF)}

We used GFCF as an independent growth in Multiple Regression Model. Quarterly data cover the period from 1976_1995 obtained from WBI. GFCF measured in Millions of US\$. The finding revealed that Mauritania real GFCF was 23.42 Million US\$. The Minimum value was

\begin{tabular}{|l|l|l|l|}
\hline & LOGGDP & LOGFDI & LOGGFCF \\
\hline Mean & 24.80329 & 15.52075 & 23.42091 \\
\hline Median & 24.75002 & 15.52027 & 23.43083 \\
\hline Maximum & 25.93635 & 17.96236 & 25.10333 \\
\hline Minimum & 23.88494 & 14.12910 & 22.42348 \\
\hline Std. Dev. & 0.660647 & 1.033912 & 0.655725 \\
\hline
\end{tabular}

Table 1: Descriptive Statistic, Source: E-Views 6.

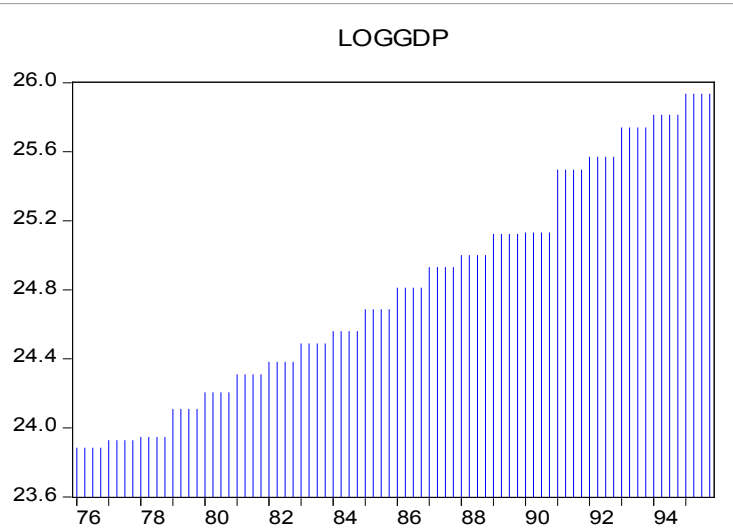

Figure 1: Mauritania's LOGGDP (1976-1995/ Quarterly).

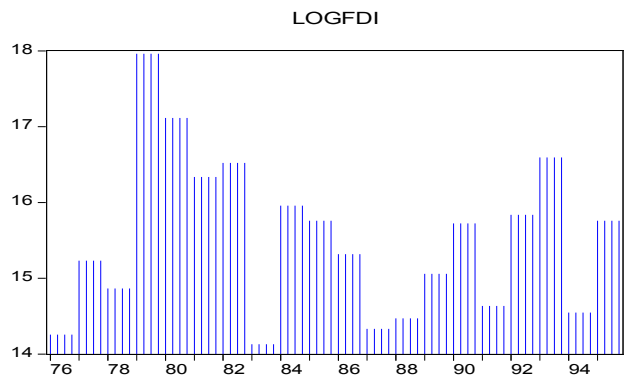

Figure 2: Multiple Regression ModelFDI (1976-1995/ Quarterly)

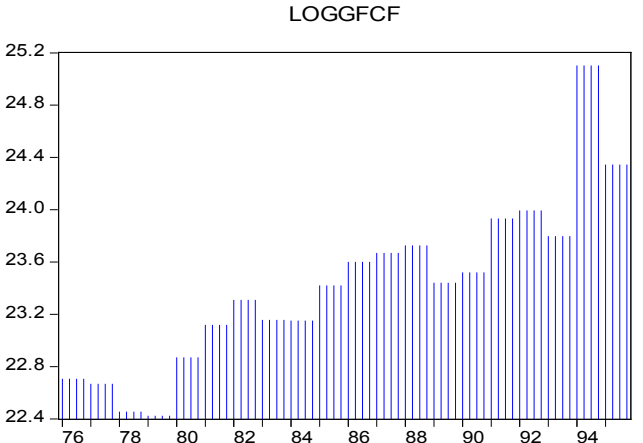

Figure 3: Multiple Regression ModelGFCF (1976-1995/ Quarterly).

22.42 Million US\$, while Maximum value recorded 25.10 Million US\$ (Figure 3)

\section{Augmented Dickey-Fuller (ADF) unit root test}

The unit root test has been applied to check whether the variables are stationary or not. The test carried out through Augmented Ducky Fuller (ADF) method as suggested by Engel and Granger (1987). The (ADF) analysis carried at both level and difference. The null hypothesis in ADF test is that there is presence of unit root. The result of (ADF) test is indicating in the following Table 2.

1\% Critical Value $\quad-3.525619$ 


\begin{tabular}{|l|l|l|l|}
\hline Variables & Levels Data & First Differences & Status \\
\hline LOGGDP & 0.452219 & -2.819407 & $\mathrm{I}(1)$ \\
\hline LOGFDI & -3.056340 & -6.627344 & $\mathrm{I}(0)$ \\
\hline LOGGFCF & -1.209058 & -6.592187 & $\mathrm{I}(1)$ \\
\hline
\end{tabular}

Table 2: Augmented Dickey-Fullers (ADF), Source: Eveiws 6.

\begin{tabular}{|l|c|c|c|}
\hline Null Hypothesis: & Obs & F-Statistic & Prob. \\
\hline LOGFDI does not Granger Cause LOGGDP & 78 & 0.11689 & 0.8898 \\
\hline LOGGDP does not Granger Cause LOGFDI & & 0.35370 & 0.7033 \\
\hline
\end{tabular}

Table 3: Granger Causality Test Source: Eveiws 6.

\begin{tabular}{|l|l|l|l|l|l|}
\hline Country & Variables & Coefficients & P-value & F-statistic & R-square \\
\hline \multirow{2}{*}{ Mauritania } & FDI & 0.085614 & 0.0040 & 226.8974 & 0.854935 \\
\cline { 2 - 6 } & GFCF & 0.960185 & 0.0000 & & \\
\hline
\end{tabular}

Table 4: Summary of OLS Results GDP, FDI and GFCF, Source: E-veiws 6.

$$
\begin{array}{lll}
5 \% & \text { Critical Value } & -2.902953 \\
10 \% & \text { Critical Value } & -2.588902
\end{array}
$$

\section{Interpretation of unit root test result}

The result of Unit Root Test indicated that all the variables included in the model were not stationary at level except FDI. That can be seen through comparing the critical value with the ADF value, when the critical value is greater that $\mathrm{ADF}$ value meaning that the variable is not stationary. However, when the critical value of the variables is less than the $\mathrm{ADF}$ value the variable is stationary.

\section{The granger causality test}

To explain the granger causality test, we often asked questions such as "is GDP that causes FDI or is FDI that causes GDP?" We test for the absence of Granger causality by estimating the following VAR model:

$\mathrm{GDP}=\Sigma \alpha_{\mathrm{i}} \mathrm{FDlt}-3+\Sigma \beta \mathrm{j}$ GDPt-3+ U1t

$\mathrm{FD} 1=\Sigma \lambda$ FDIt $-3+\Sigma \delta$ iGDPt $-3+\mathrm{U} 2 \mathrm{t}$

$\alpha, \beta, \lambda$ and $\delta$ are parameters to be estimated, and Ult and U2t are the error term.

Granger causality test was applied in order to determine the presence of the relationship among variables and its direction (Granger, 1969 ) is carried out using E-views 6. The findings of Granger Causality Test between FDI and GDP indicated in the following Table 3:

The result in Table 3 shows that we cannot reject the null hypothesis, which means that GDP does not Grange cause FDI and vice-versa. Therefore, there was no causality between FDI and GDP of Mauritania since all $\mathrm{P}$-value is greater than $5 \%$.

\section{Ordinary Least Square (OLS)}

OLS method has applied in this study. The summary of the test indicated that the model of the study is well fitted. All the variables in the model are statistically significant. The coefficient of the constant variable recorded 3.84 which indicate a positive relationship between the constant parameter and the Gross Domestic Product. Although, the constant parameter has no significant effect on the model rather than reflecting the value of GDP when other independent variables are help constant. The summary of OLS result showed in the following Table 4.

\section{Interpretation of OLS result}

The empirical results are presented by the above table. The slope coefficients of the both inputs (FDI) and (GFCF) in Multiple Regression Analyses have positive impact on GDP. If one percent change in FDI occurs, it will bring about $0.085 \%$ change in GDP and 1 percent change in GFCF will bring $0.96 \%$ change in GDP by holding other variables constant. Estimates (FDI and GFCF) are highly significant. As the value of $\mathrm{F}$ is too high i.e., 226.8974 and the value of $\mathrm{P}$ is so small i.e., 0.000 we can deduce that model is overall very much significant and the results are not by chance. The r-square of this model is 0.85 that means only $15 \%$ variation in the model is unexplained by FDI and GFCF whereas remaining variation (85\%) is explained by FDI and GDP.

\section{Conclusion and Recommendation}

The main objective of this study is to investigate the impact of Foreign Direct Investment (FDI) on the economic growth of Mauritania for the period 1976 to 1995 . In an economy, direct investment is suggestive of a positive trend of investment which ultimately translates in increase in GDP and economic growth of the country. This can also be proved from the findings of this research that increasing trend of FDI also increases the GDP of the country. The Granger Causality test indicates no causality between GDP and FDI in the period under investigation. The significance of FDI in generating the target growth rate in Mauritania may be restricted by the level of infrastructure, environmental business, Economic reform, and political stability. Results of this study suggested some policy implications. The government in order to gain confidence of investors should focus on the following areas:

\section{Improvement of infrastructure}

In any economy infrastructure plays a very crucial role to develop and encourage the growth of the state. These states that have a strong physical infrastructure are considered as the best nations for attracting FDI. Thus, Mauritania government should give full consideration to improve and develop the infrastructure across the country.

\section{Create friendly environmental business}

Pleasant business environment is among the properties to attract FDI. Mauritanian in order to benefit from FDI should focus on improving human capital, and technology jobs. World Bank report 2013 released that Mauritania doing business index is 164 out of 185 which is not conducive to doing business. These factors are including, lack of world class ports, airports, road. Other problems are that of norms of registering property, protection of investors, excessive bureaucracy, lack of rationale tax structure, competition rules and time taken in enforcing contracts.

\section{Economics reform}

Economic reformation refers to the transformation of property from less productive to more productive sectors of the economy. Real growth of production is directly correlated with the effective process of economy restructuring from the less productive to the more productive sectors of the economy. FDI may be involved in the transfer of resources from less productive to more productive sectors of the economy.

\section{Ensuring political stability}

The successful and energetic market economy requires political stability for its best achievable outcomes. Political instability generates economic insecurity because of turn down in investment. Mauritania 
Citation: Ould L (2015) An Investigation of the Impact of Foreign Direct Investment on Economic Growth: A Case Study of Mauritania. Int J Econ Manag Sci 4: 224. doi: 10.4172/2162-6359.1000224

Page 5 of 5

such as other African country is suffered from the political conflict. From 1976 to 2008 Mauritania has witnessed series of military coups which were enough to drag down the democratic process and create severe polarization inside political classes. This political instability has reduced the confidence of investors in the country.

\section{References}

1. Obadan Ml (2004) Foreign Capital Flows and External Debt: Perspectives on Nigeria and the LDCs Group, Broadway Press Ltd, Ibadan, Nigeria.

2. Muhammad A (2007) Economic Growth and Foreign Direct Investment: The Role of Domestic Financial Sector, PIDE Working Papers.

3. Amna MG, Imran UC, Salman AS (2010) Impact of Foreign Direct Investment on Economic Growth: A Case Study of Pakistan, Journal of Management and Social Sciences, 84-92.

4. Dunning J, Hamdani A (1997) The new globalism and developing countries, United Nations University Press, New York.

5. UNCTAD (2013) Nigeria Tops List of Foreign Direct Investments in Africa, Press PR, Geneva.

6. Mahmoud MO, Limam, Abduh M (2014) The Role of Awareness in Islamic Bank Patronizing Behaviorof Mauritanian: An Application of TRA, Journal of Islamic Finance (IIUM Institute of Islamic Banking and Finance) 3: 30-38.

7. Alfaro L, Chanda A, Kalemli-Ozcan S, Sayek S (2004) FDI and economic growth: The role of local financial markets. Journal of international economics 64: 89-112.

8. Frimpong JM, Oteng-Abayie EF (2006) Bivariate causality analysis between FDI inflows and economic growth in Ghana.
9. Ayanwale AB (2007) FDI and economic growth: Evidence from Nigeria, Edited by AERC Research Paper 165, African Economic Research Consortium.

10. Herzer D, Klasen S, Nowak-Lehmann DF (2006) In search of FDI-led growth in developing countries: The way forward, Ibero American Institute for Economic Research 25: 793-810.

11. Chih-Chiang, Wu Jyun-Yi, Hsu (2008) Does Foreign Direct Investment Promote Economic Growth? Evidence from a Threshold Regression Analysis, Bulletin Economics.

12. Nuzhat $F(2009)$ Impact of Foreign Direct Investment on Economic, Internationa Review of Business Research Papers 5: 5.

13. Abel EE, Nikki C (2011) FDI flows to Sub-Saharan Africa: the impact of finance, institution and natural resource endowment, Department of Economics and Economic History.

14. Behname M (2012) Foreign direct investment and economic growth: Evidence from southern Asia, Atlantic Review of Economics 2.

15. Onakoya $A B$ (2012) Foreign direct investments and economic growth in Nigeria: A disaggregated sector analysis, 3.

16. Abbas Q, Akbar S, Nasir A, Amanullah H, Naseem M (2011) Impact of Foreign Direct Investment, Global Journal of Management and Business Research 11.

17. Esther OA, Folorunso SA (2011) The role of foreign direct investment in economic development: A study of Nigeria, World Journal of Entrepreneurship, Management and Sustainable Development.

18. Zakia M, Ziad A (2007) The impact of foreign direct investment and imports on economic growth: The case of Jordan, Journal of Economic and Administrative Sciences.

19. Kashif $Y$, Muhammad $R$ (2013) The Impact of foreign direct investment on Pakistan economic growth, Interdisciplinary journal of contemporary research in business 4: 287-296. 